\title{
Cerebrospinal Fluid Analysis Should Be Considered in Patients with Cognitive Problems
}

\author{
Henrik Zetterberg, Niklas Mattsson, and Kaj Blennow \\ Department of Psychiatry and Neurochemistry, Institute of Neuroscience and Physiology, \\ The Sahlgrenska Academy at University of Gothenburg, 43180 Mölndal, Sweden
}

Correspondence should be addressed to Henrik Zetterberg, henrik.zetterberg@gu.se

Received 16 January 2010; Accepted 2 March 2010

Academic Editor: Lucilla Parnetti

Copyright ( $\odot 2010$ Henrik Zetterberg et al. This is an open access article distributed under the Creative Commons Attribution License, which permits unrestricted use, distribution, and reproduction in any medium, provided the original work is properly cited.

Hepatologists assay liver enzymes and cardiologists structural heart proteins in serum to diagnose and monitor their patients. This way of thinking has not quite made it into the memory clinics yet, in spite of the availability of validated cerebrospinal fluid biomarkers for key pathological events in the brain in neurodegeneration. Here, we argue that a spinal tap should be considered in all patients who seek medical advice for memory problems and list the highly relevant clinical questions CSF analyses can address.

\section{Introduction}

Memory problems may be caused by a wide range of neuropsychiatric diseases, including Alzheimer's disease $(\mathrm{AD})$, vascular dementia $(\mathrm{VaD})$, dementia with Lewy bodies, frontotemporal dementia (FTD), to mention a few [1]. Cognitive symptoms may also arise secondary to depression, neuroinflammation and various somatic illnesses. Today, patients with memory problems seek medical advice much earlier than 10 years ago. It is difficult to differentiate benign cognitive deficiencies from $\mathrm{AD}$ or other primary neurodegenerative diseases. Memory problems secondary to other diseases may also present a diagnostic challenge.

Patients with memory complaints most often undergo extensive clinical and neuropsychological assessments, and often also one or more brain imaging investigations. We argue that CSF analysis should be considered in the diagnostic work-up of all patients with memory problems to answer a number of highly relevant questions discussed below. Fear of spinal tap-related side-effects should not preclude CSF analyses, since complications are very rare in the elderly, provided that regular precautions well known to any trained physician are taken [2-4].

\section{Does the Patient Suffer from Brain Amyloid Pathology?}

The robust association of brain amyloid pathology with $\mathrm{AD}$ makes this question highly relevant. The easiest and most cost-effective way of giving it a reliable answer is to analyse CSF for the 42 amino acid form of amyloid $\beta$ (A $\beta 1-42$ ). Low CSF levels indicate retention of $A \beta 1-42$ in the brain parenchyma [5-8]. This seems to be the earliest biochemical change during the course of $\mathrm{AD}$ [9-11]. Low levels of $\mathrm{A} \beta 1$ 42 may be seen Creutzfeldt-Jakob disease (CJD), also in the absence of significant amounts of brain amyloid pathology [12].

\section{Does the Patient Suffer from Neurofibrillary Tangle Pathology?}

Tau expression is high in nonmyelinated cortical axons where it serves as a microtubule-stabilizing protein [13]. Hyperphosphorylation of tau causes the protein to detach from the microtubules. This process promotes axonal and synaptic plasticity in the developing brain $[14,15]$, but is pathological in the adult brain and specifically related 
TABLE 1: CSF biomarkers of pathological findings in relation to differential diagnoses in memory clinic patients.

\begin{tabular}{|c|c|c|c|c|c|c|}
\hline Diagnosis & $\begin{array}{l}\text { Amyloid pathology } \\
\quad(\mathrm{A} \beta 1-42)\end{array}$ & $\begin{array}{l}\text { Tangle pathology } \\
\text { (P-tau) }\end{array}$ & $\begin{array}{l}\text { Cortical axonal } \\
\text { damage (T-tau) }\end{array}$ & $\begin{array}{l}\text { Sub-cortical axonal } \\
\text { damage (NFL) }\end{array}$ & $\begin{array}{c}\text { Blood-brain } \\
\text { barrier dysfunction } \\
\text { (CSF/serum } \\
\text { albumin ratio) }\end{array}$ & $\begin{array}{c}\text { Inflammation } \\
\text { (CSF cell counts, } \\
\text { IgG or IgM } \\
\text { production) }\end{array}$ \\
\hline $\mathrm{AD}$ & Yes & Yes & Yes & No & No & No \\
\hline $\mathrm{VaD}$ & No & No & $\begin{array}{c}\text { Yes } \\
\text { (especially in } \\
\text { relation to new } \\
\text { brain infarcts) }\end{array}$ & Yes & Yes & No \\
\hline FTD & No & $\begin{array}{c}\text { Yes } \\
\text { (but not in CSF) }\end{array}$ & $\begin{array}{c}\text { Yes } \\
\text { (mild) }\end{array}$ & Yes & No & No \\
\hline LBD & Yes & No & $\begin{array}{c}\text { Yes } \\
\text { (mild) }\end{array}$ & No & No & No \\
\hline $\mathrm{PD}$ & No & No & No & No & No & No \\
\hline PSP & No & $\begin{array}{c}\text { Yes } \\
\text { (but not in CSF) }\end{array}$ & No & Yes & No & No \\
\hline CJD & No & No & $\begin{array}{c}\text { Yes } \\
\text { (severe) }\end{array}$ & $\begin{array}{c}\text { Yes } \\
\text { (mild to moderate) }\end{array}$ & No & No \\
\hline Depression & No & No & No & No & No & No \\
\hline Lyme disease & No & No & No & $\begin{array}{c}\text { Yes } \\
\text { (mild) }\end{array}$ & Yes & $\begin{array}{c}\text { Yes } \\
\text { (especially IgM) }\end{array}$ \\
\hline $\begin{array}{l}\text { Multiple } \\
\text { sclerosis }\end{array}$ & No & No & No & Yes & $\begin{array}{l}\text { No } \\
\text { (mild in 10\%) }\end{array}$ & $\begin{array}{c}\text { Yes } \\
\text { (especially } \operatorname{Ig} G)\end{array}$ \\
\hline Acute stroke & No & No & Yes & Yes & Yes & No \\
\hline Normal aging & No & No & No & No & No & No \\
\hline
\end{tabular}

Abbreviations: $\mathrm{CSF}=$ cerebrospinal fluid; $\mathrm{A} \beta 1-42=$ the 42 amino acid isoform of amyloid $\beta$; P-tau = hyperphosphorylated tau; $\mathrm{T}$-tau $=$ total tau; NFL = neurofilament light; $\mathrm{AD}=$ Alzheimer's disease; VaD = vascular dementia; FTD = frontotemporal dementia; LBD = Lewy body dementia; PD = Parkinson's disease; $\mathrm{PSP}=$ progressive supranuclear palsy; CJD = Creutzfeldt-Jakob disease .

to a group of disorders referred to as tauopathies, which includes AD and some forms of FTD [16].

Elevated CSF levels of hyperphosphorylated tau (P-tau) protein are the most specific finding suggesting an ongoing $\mathrm{AD}$ process in the brain [17]. P-tau levels correlate with cognitive decline in patients with mild cognitive impairment (MCI) [18] and with neocortical neurofibrillary pathology in $\mathrm{AD}$ [19]. The reason for the lack of P-tau increase in FTD and other pure tauopathies such as progressive supranuclear palsy and corticobasal degeneration is to date unknown $[20,21]$.

\section{Are there Biochemical Signs of Cortical Axonal Degeneration and How Active Is this Process?}

Pathogenic processes that damage axons in the cortex result in increased CSF levels of total tau (T-tau, i.e., all isoforms irrespective of phosphorylation state). T-tau is a dynamic marker of the intensity of the axonal degeneration/damage: the more pronounced increase, the more intense degenerative process, the faster disease progression [17]. Very high CSF T-tau levels are always seen in CJD [22-25], and can be seen in stroke and brain trauma, in which T-tau predicts clinical course and/or outcome
[26-28]. The cortical axonal degeneration in AD makes elevated CSF T-tau an obligatory finding. Consequently, a clinical diagnosis of AD should be reconsidered in the absence of tau elevation. Very high levels predict a rapid cognitive decline in $\mathrm{AD}$ [29-31] and short survival in DLB [32].

Together, CSF biomarkers of amyloid pathology (A $\beta 1$ 42 ), tangle pathology (P-tau) and cortical axonal degeneration (T-tau) identify AD with dementia and prodromal AD in patients with MCI with 75-95\% sensitivity and specificity [33-36].

\section{Are there Biochemical Signs of Sub-Cortical Axonal Degeneration and How Active Is this Process?}

The best-established CSF biomarker for sub-cortical axonal degeneration/damage is neurofilament light protein (NFL). This type of axonal degeneration is frequently seen in $\mathrm{VaD}$ [37-39], FTD [40] and a number of inflammatory conditions, including MS [41] and AIDS dementia [42]. Elevated CSF NFL levels indicate a sub-cortical disease process and help in differentiating pure $\mathrm{AD}$ from the conditions listed above. Combined T-tau and NFL increases indicate mixed forms of $\mathrm{AD}$ and cerebrovascular disease. 


\section{Is the Blood-Brain Barrier Damaged?}

The best-established biomarker for the integrity of the blood-brain barrier is the ratio of the albumin concentration in CSF to serum (the CSF/serum albumin ratio). Strictly speaking, the CSF/serum albumin ratio is a direct measure of the blood-CSF barrier [43]. However, leaking blood vessels in the brain will eventually result in higher CSF/serum albumin ratio through release of albumin to the brain interstitial fluid which communicates freely with the CSF. Typically, the $\mathrm{CSF} /$ serum albumin ratio is normal in patients with pure $\mathrm{AD}[44]$, whereas patients with vascular dementia generally present with elevated albumin ratio [45]. The same finding is often present in Lyme disease (neuroborreliosis), where one also may find increased numbers of CSF monocytes and signs of immunoglobulin production within the CNS [46]. Blockage of the spinal canal which, by impairing the flow of CSF distal to the block, allows longer for equilibrium with the circulation and so brings the composition of the CSF nearer to that of plasma (Froin's syndrome), results in elevated CSF/serum albumin ratio in the absence of bloodbrain barrier damage.

\section{Are there Biochemical Signs of Neuroinflammation?}

Basic CSF examinations of inflammatory activity, including white blood cell count and general signs of IgG or IgM production within the CNS are generally negative in $\mathrm{AD}$ and other primary neurodegenerative diseases [47]. Distinct positive results speak against pure $\mathrm{AD}$ and should motivate further investigation of the patient to exclude neuroborreliosis, multiple sclerosis and other neuroinflammatory conditions that may contribute to the cognitive symptoms.

\section{Conclusions}

Robust answers to the clinically relevant questions listed above are warranted in the professional evaluation of any patient with memory complaints. Valid CSF biomarkers are available for amyloid pathology (A $\beta 1-42)$, neurofibrillary pathology (P-tau), cortical axonal degeneration/damage (T-tau), sub-cortical axonal degeneration/damage (NFL), blood-brain barrier function (CSF/serum albumin ratio) and neuroinflammation (CSF cell counts, IgG and IgM oligoclonal bands and concentrations). The biochemical data should be interpreted with great care together with the whole clinical picture, as well as findings in neuropsychological testing and neuroimaging investigations. Typical changes in relation to different diagnostic entities are summarised in Table 1.

\section{Acknowledgments}

Work in the authors' laboratory is supported by the Swedish Research Council, the Royal Swedish Academy of Sciences, and Alzheimer's Association.

\section{References}

[1] K. Blennow, M. J. de Leon, and H. Zetterberg, "Alzheimer's disease," The Lancet, vol. 368, no. 9533, pp. 387-403, 2006.

[2] N. Andreasen, L. Minthon, P. Davidsson, et al., "Evaluation of CSF-tau and CSF-A $\beta 42$ as diagnostic markers for Alzheimer disease in clinical practice," Archives of Neurology, vol. 58, no. 3, pp. 373-379, 2001.

[3] K. Blennow, A. Wallin, and O. Hager, "Low frequency of post-lumbar puncture headache in demented patients," Acta Neurologica Scandinavica, vol. 88, no. 3, pp. 221-223, 1993.

[4] E. R. Peskind, R. Riekse, J. F. Quinn, et al., "Safety and acceptability of the research lumbar puncture," Alzheimer Disease and Associated Disorders, vol. 19, no. 4, pp. 220-225, 2005.

[5] D. Strozyk, K. Blennow, L. R. White, and L. J. Launer, "CSF A $\beta 42$ levels correlate with amyloid-neuropathology in a population-based autopsy study," Neurology, vol. 60, no. 4, pp. 652-656, 2003.

[6] A. M. Fagan, M. A. Mintun, R. H. Mach, et al., "Inverse relation between in vivo amyloid imaging load and cerebrospinal fluid Abeta 42 in humans," Annals of Neurology, vol. 59, no. 3, pp. 512-519, 2006.

[7] A. Forsberg, H. Engler, O. Almkvist, et al., "PET imaging of amyloid deposition in patients with mild cognitive impairment," Neurobiology of Aging, vol. 29, no. 10, pp. 1456-1465, 2008.

[8] T. Grimmer, M. Riemenschneider, H. Forstl, et al., "Beta amyloid in Alzheimer's disease: increased deposition in brain is reflected in reduced concentration in cerebrospinal fluid," Biological Psychiatry, vol. 65, no. 11, pp. 927-934, 2009.

[9] A. M. Fagan, D. Head, A. R. Shah, et al., "Decreased cerebrospinal fluid $\mathrm{A} \beta 42$ correlates with brain atrophy in cognitively normal elderly," Annals of Neurology, vol. 65, no. 2, pp. 176-183, 2009.

[10] D. R. Gustafson, I. Skoog, L. Rosengren, H. Zetterberg, and K. Blennow, "Cerebrospinal fluid $\beta$-amyloid 1-42 concentration may predict cognitive decline in older women," Journal of Neurology, Neurosurgery and Psychiatry, vol. 78, no. 5, pp. 461464, 2007.

[11] E. Stomrud, O. Hansson, K. Blennow, L. Minthon, and E. Londos, "Cerebrospinal fluid biomarkers predict decline in subjective cognitive function over 3 years in healthy elderly," Dementia and Geriatric Cognitive Disorders, vol. 24, no. 2, pp. 118-124, 2007.

[12] M. Otto, H. Esselmann, W. Schulz-Schaeffer, et al., "Decreased $\beta$-amyloid1-42 in cerebrospinal fluid of patients with Creutzfeldt-Jakob disease," Neurology, vol. 54, no. 5, pp. 10991102, 2000.

[13] J. Q. Trojanowski, T. Schuck, M. L. Schmidt, and V. M.-Y. Lee, "Distribution of tau proteins in the normal human central and peripheral nervous system," Journal of Histochemistry and Cytochemistry, vol. 37, no. 2, pp. 209-215, 1989.

[14] S. Lovestone and C. H. Reynolds, "The phosphorylation of tau: a critical stage in neurodevelopment and neurodegenerative process," Neuroscience, vol. 78, no. 2, pp. 309-324, 1997.

[15] N. Mattsson, K. Sävman, G. Österlundh, K. Blennow, and H. Zetterberg, "Converging molecular pathways in human neural development and degeneration," Neuroscience Research, vol. 66, no. 3, pp. 330-332, 2010.

[16] C. Ballatore, V. M.-Y. Lee, and J. Q. Trojanowski, "Taumediated neurodegeneration in Alzheimer's disease and related disorders," Nature Reviews Neuroscience, vol. 8, no. 9, pp. 663-672, 2007. 
[17] H. Hampel, K. Blennow, L. M. Shaw, Y. C. Hoessler, H. Zetterberg, and J. Q. Trojanowski, "Total and phosphorylated tau protein as biological markers of Alzheimer's disease," Experimental Gerontology, vol. 45, no. 1, pp. 30-40, 2010.

[18] K. Buerger, S. J. Teipel, R. Zinkowski, et al., "CSF tau protein phosphorylated at threonine 231 correlates with cognitive decline in MCI subjects," Neurology, vol. 59, no. 4, pp. 627629, 2002.

[19] K. Buerger, M. Ewers, T. Pirttilä, et al., "CSF phosphorylated tau protein correlates with neocortical neurofibrillary pathology in Alzheimer's disease," Brain, vol. 129, no. 11, pp. 30353041, 2006.

[20] H. Bian, J. C. Van Swieten, S. Leight, et al., "CSF biomarkers in frontotemporal lobar degeneration with known pathology," Neurology, vol. 70, no. 19, pp. 1827-1835, 2008.

[21] M. Grossman, J. Farmer, S. Leight, et al., "Cerebrospinal fluid profile in frontotemporal dementia and Alzheimer's disease," Annals of Neurology, vol. 57, no. 5, pp. 721-729, 2005.

[22] K. Blennow, A. Johansson, and H. Zetterberg, "Diagnostic value of 14-3-3beta immunoblot and T-tau/P-tau ratio in clinically suspected Creutzfeldt-Jakob disease," International Journal of Molecular Medicine, vol. 16, no. 6, pp. 1147-1149, 2005.

[23] M. Riemenschneider, S. Wagenpfeil, H. Vanderstichele, et al., "Phospho-tau/total tau ratio in cerebrospinal fluid discriminates Creutzfeldt-Jakob disease from other dementias," Molecular Psychiatry, vol. 8, no. 3, pp. 343-347, 2003.

[24] M. Otto, J. Wiltfang, L. Cepek, et al., "Tau protein and 143-3 protein in the differential diagnosis of Creutzfeldt-Jakob disease," Neurology, vol. 58, no. 2, pp. 192-197, 2002.

[25] M. Otto, J. Wiltfang, H. Tumani, et al., "Elevated levels of tau-protein in cerebrospinal fluid of patients with CreutzfeldtJakob disease," Neuroscience Letters, vol. 225, no. 3, pp. 210 212, 1997.

[26] C. Hesse, L. Rosengren, N. Andreasen, et al., "Transient increase in total tau but not phospho-tau in human cerebrospinal fluid after acute stroke," Neuroscience Letters, vol. 297, no. 3, pp. 187-190, 2001.

[27] M. Ost, K. Nylen, L. Csajbok, et al., "Initial CSF total tau correlates with 1-year outcome in patients with traumatic brain injury," Neurology, vol. 67, no. 9, pp. 1600-1604, 2006.

[28] H. Zetterberg, M. A. Hietala, M. Jonsson, et al., "Neurochemical aftermath of amateur boxing," Archives of Neurology, vol. 63, no. 9, pp. 1277-1280, 2006.

[29] K. Samgard, H. Zetterberg, K. Blennow, O. Hansson, L. Minthon, and E. Londos, "Cerebrospinal fluid total tau as a marker of Alzheimer's disease intensity," International Journal of Geriatric Psychiatry, vol. 25, no. 4, pp. 403-410, 2009.

[30] E. S. Blom, V. Giedraitis, H. Zetterberg, et al., "Rapid progression from mild cognitive impairment to Alzheimer's disease in subjects with elevated levels of tau in cerebrospinal fluid and the APOE epsilon4/epsilon4 genotype," Dementia and Geriatric Cognitive Disorders, vol. 27, no. 5, pp. 458-464, 2009.

[31] K. Buerger, M. Ewers, N. Andreasen, et al., "Phosphorylated tau predicts rate of cognitive decline in MCI subjects: a comparative CSF study," Neurology, vol. 65, no. 9, pp. 15021503, 2005.

[32] F. Bostrom, O. Hansson, K. Blennow, et al., "Cerebrospinal fluid total tau is associated with shorter survival in dementia with lewy bodies," Dementia and Geriatric Cognitive Disorders, vol. 28, no. 4, pp. 314-319, 2009.
[33] O. Hansson, H. Zetterberg, P. Buchhave, E. Londos, K. Blennow, and L. Minthon, "Association between CSF biomarkers and incipient Alzheimer's disease in patients with mild cognitive impairment: a follow-up study," Lancet Neurology, vol. 5, no. 3, pp. 228-234, 2006.

[34] N. Mattsson, H. Zetterberg, O. Hansson, et al., "CSF biomarkers and incipient Alzheimer disease in patients with mild cognitive impairment," Journal of the American Medical Association, vol. 302, no. 4, pp. 385-393, 2009.

[35] L. M. Shaw, H. Vanderstichele, M. Knapik-Czajka, et al., "Cerebrospinal fluid biomarker signature in Alzheimer's disease neuroimaging initiative subjects," Annals of Neurology, vol. 65, no. 4, pp. 403-413, 2009.

[36] P. J. Visser, F. Verhey, D. L. Knol, et al., "Prevalence and prognostic value of CSF markers of Alzheimer's disease pathology in patients with subjective cognitive impairment or mild cognitive impairment in the DESCRIPA study: a prospective cohort study," The Lancet Neurology, vol. 8, no. 7, pp. 619-627, 2009.

[37] L. E. Rosengren, J.-E. Karlsson, M. Sjogren, K. Blennow, and A. Wallin, "Neurofilament protein levels in CSF are increased in dementia," Neurology, vol. 52, no. 5, pp. 1090-1093, 1999.

[38] A. Agren-Wilsson, A. Lekman, W. Sjoberg, et al., "CSF biomarkers in the evaluation of idiopathic normal pressure hydrocephalus," Acta Neurologica Scandinavica, vol. 116, no. 5, pp. 333-339, 2007.

[39] A. Wallin and M. Sjogren, "Cerebrospinal fluid cytoskeleton proteins in patients with subcortical white-matter dementia," Mechanisms of Ageing and Development, vol. 122, no. 16, pp. 1937-1949, 2001.

[40] D. de Jong, R. W. Jansen, Y. A. L. Pijnenburg, et al., "CSF neurofilament proteins in the differential diagnosis of dementia," Journal of Neurology, Neurosurgery and Psychiatry, vol. 78, no. 9, pp. 936-938, 2007.

[41] N. Norgren, P. Sundström, A. Svenningsson, L. Rosengren, T. Stigbrand, and M. Gunnarsson, "Neurofilament and glial fibrillary acidic protein in multiple sclerosis," Neurology, vol. 63, no. 9, pp. 1586-1590, 2004.

[42] M. Gisslen, L. Hagberg, B. J. Brew, P. Cinque, R. W. Price, and L. Rosengren, "Elevated cerebrospinal fluid neurofilament light protein concentrations predict the development of AIDS dementia complex," Journal of Infectious Diseases, vol. 195, no. 12, pp. 1774-1778, 2007.

[43] H. Reiber and J. B. Peter, "Cerebrospinal fluid analysis: diseaserelated data patterns and evaluation programs," Journal of the Neurological Sciences, vol. 184, no. 2, pp. 101-122, 2001.

[44] K. Blennow, A. Wallin, P. Fredman, I. Karlsson, C. G. Gottfries, and L. Svennerholm, "Blood-brain barrier disturbance in patients with Alzheimer's disease is related to vascular factors," Acta Neurologica Scandinavica, vol. 81, no. 4, pp. 323-326, 1990.

[45] A. Wallin, K. Blennow, and L. Rosengren, "Cerebrospinal fluid markers of pathogenetic processes in vascular dementia, with special reference to the subcortical subtype," Alzheimer Disease and Associated Disorders, vol. 13, no. 3, pp. S102-S105, 1999.

[46] H. Tumani, G. Nolker, and H. Reiber, "Relevance of cerebrospinal fluid variables for early diagnosis of neuroborreliosis," Neurology, vol. 45, no. 9, pp. 1663-1670, 1995.

[47] K. Blennow, A. Wallin, P. Fredman, C. G. Gottfries, I. Karlsson, and L. Svennerholm, "Intrathecal synthesis of immunoglobulins in patients with Alzheimer's disease," European Neuropsychopharmacology, vol. 1, no. 1, pp. 79-81, 1990. 


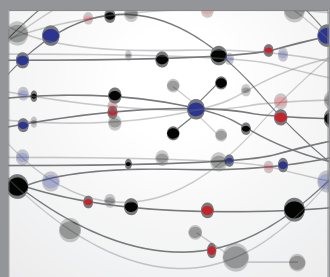

The Scientific World Journal
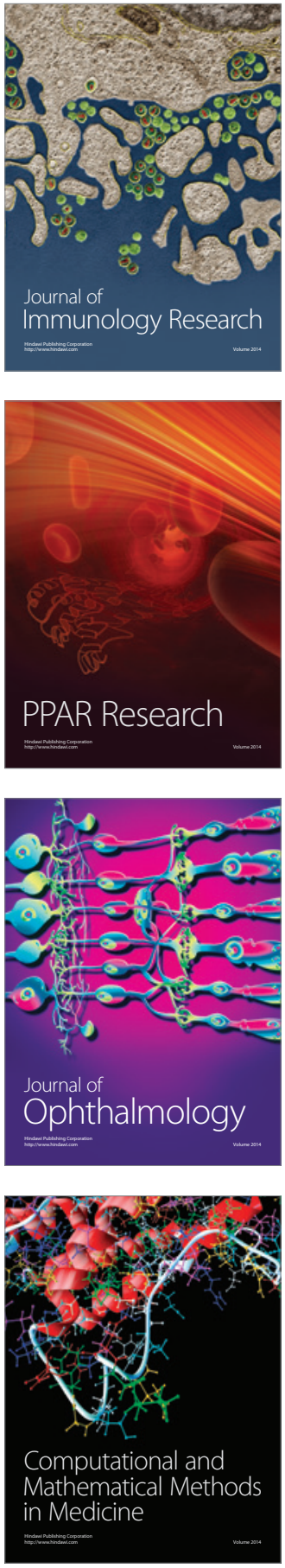

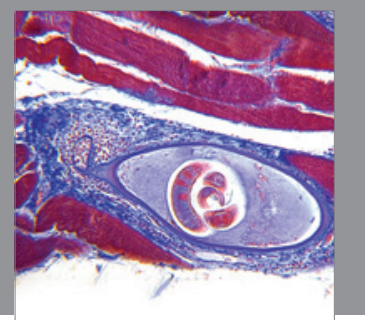

Gastroenterology

Research and Practice
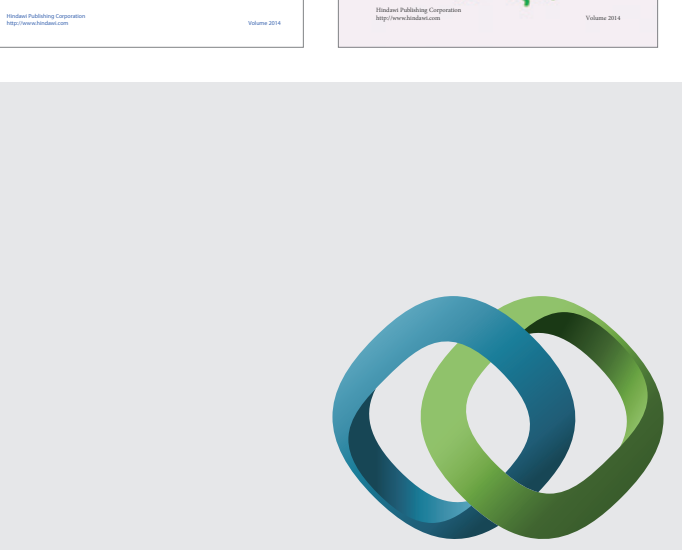

\section{Hindawi}

Submit your manuscripts at

http://www.hindawi.com
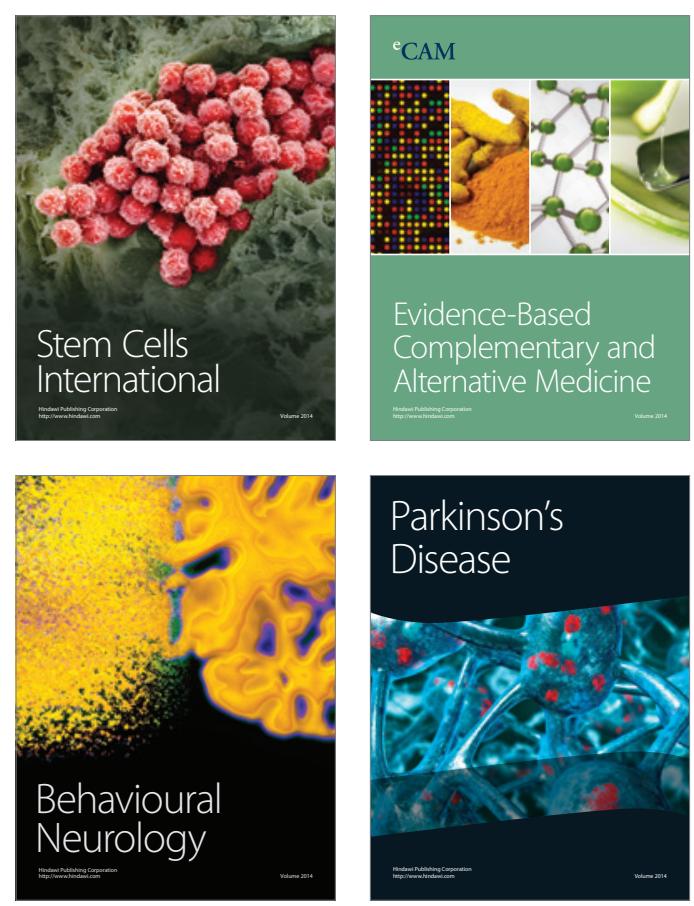

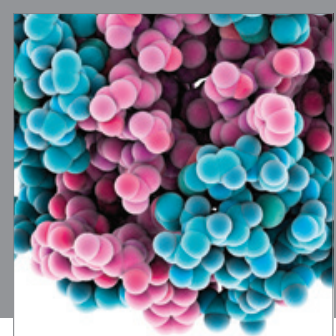

Journal of
Diabetes Research

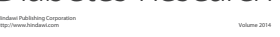

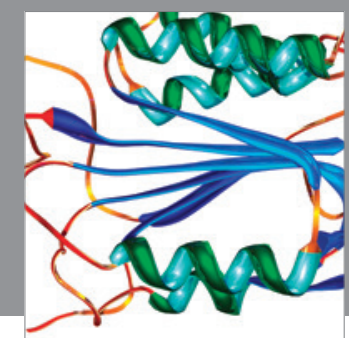

Disease Markers
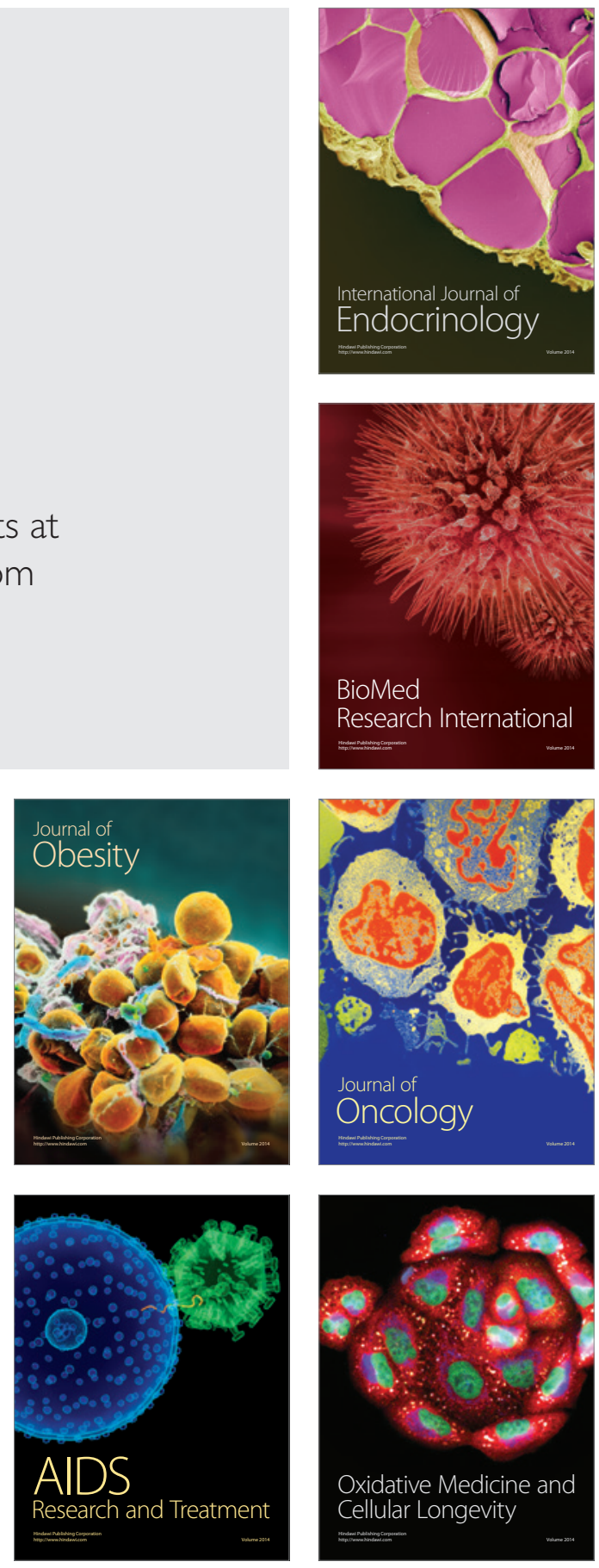